\title{
Evidence of complement clq tumor necrosis factor- related protein 4 in the sea star asterias rubens: a new sea star cytokine
}

\begin{abstract}
In the present paper, we show a survey of the A. rubens sea star genome for genes associated with NF-kappa-B proteins implied in the immune response: the Complement C1q tumor necrosis factor-related protein 4 (a cytokine) which modulates the NFkappa-B action in mammals, is described in sea star model.
\end{abstract}

Keywords: nf-kappa-b, cytokines, sea star, invertebrate, rubens sea star genome
Volume 2 Issue 2 - 2017

\section{Michel Leclerc}

Doctor es Sciences University of Orléans, France

Correspondence: Michel Leclerc, Doctor es Sciences University of Orléans, 556 rue Isabelle Romée, Sandillon 45640, France,Email mleclerc45@gmail.com

Received: January 25, 2017 | Published: February 23, 2017

\section{Introduction}

Recently, we discovered the interleukin 17 receptor $\mathrm{B}^{1}$ which mediated the activation of NF-kappa-B proteins in mammals. ${ }^{2}$ Then we shown the existence of NF-kappa-B genes in the sea star Asterias rubens. ${ }^{3}$ A survey of the one genome allowed us to discover among the complement components genes, a gene which codes for a particular protein : the complement $\mathrm{C} 1 \mathrm{q}$ tumor necrosis factor-related protein 4 , we study now.

\section{Material and methods}

Sea stars were obtained from the Biology Institute (Gothenburg University).

Immunizations, genomic studies were already described. ${ }^{3}$

After ligation of adapters for Illumina's GSII sequencing system, the cDNA was sequenced on the Illumina GSII platform sequencing. $1.100 \mathrm{bp}$ from one side of the approximately $200 \mathrm{bp}$ fragments sequences were assembled using Velvet. ${ }^{4}$

\section{Results}

Results were given in controls (Non-immunized animals to HRP) (Horse-radish peroxydase)

I. Control: Contig135 sp|Q8R066|C1QT4_MOUSE Complement $\mathrm{C} 1 \mathrm{q}$ tumor necrosis factor-related protein $4 \mathrm{OS}=$ Mus musculus $\mathrm{GN}=\mathrm{C} 1 \mathrm{qtnf} 4 \mathrm{PE}=1 \mathrm{SV}=1$ Other results appeared in immunized sea stars (HRP).

II. HRP: Contig1583|m.5343 sp|Q8R066|C1QT4_MOUSE Complement $\mathrm{C} 1 \mathrm{q}$ tumor necrosis factor-related protein $4 \mathrm{OS}=\mathrm{Mus}$ musculus $\mathrm{GN}=\mathrm{C} 1 \mathrm{qtnf} 4 \mathrm{PE}=1 \mathrm{SV}=1$.

\section{Discussion \& conclusion}

In mouse, the nuclear factor Kappa B (NF-KappaB) signaling pathway, regulates immune and inflammatory responses and is implicated in the pathogenesis of multiple diseases. The principal mechanism controlling NF-Kappa B activation depends on the association of NF-Kappa B transcription factor dimers with Ikappa B molecules, which prevents the accumulation of NF-Kappa B in the nucleus and the activation of target gene transcription.

Since NF-Kappa B gene has been discovered in sea star genome. ${ }^{3}$ We may envisage a similar pathway in it, corroborated by the presence of the $\mathrm{Clq}$ tumor necrosis factor related protein 4: a new sea star cytokine which induces activation of sea star NF-Kappa B.

\section{Acknowledgements}

None.

\section{Conflict of interest}

The author declares no conflict of interest.

\section{References}

1. Leclerc M. Am J Immunol. 2013;9:65.

2. Hayden MS, West AP, Ghosh S. NF-kappaB and the immune response. Oncogene. 2006;25(51):6758-6780.

3. Leclerc M, Kresdorn N, Horres R. Asterias rubens: Evidence of NFkappa B genes. Meta gene. 2016;8:30-32.

4. Zerbino DR, Birney E. Velvet: algorithms for de novo short read assembly using de Bruijn graphs. Genome Res. 2008;18(5):821-829. 